\title{
PHYTOPLANKTON DYNAMICS IN ESTUARY OF ROSETTA BRANCH OF RIVER NILE, EGYPT
}

\section{Samiha M. Gharib}

National Institute of Oceanography and Fisheries, Kayet Bay, Alexandria, Egypt

Key words: Phytoplankton biomass, physico-chemical parameters, River Nile Rosetta Estuary.

\section{ABSTRACT}

Dhytoplankton biomass and species composition in Rosetta Estuary was analyzed at seven stations based on a programme of monthly sampling from February 2004 to January 2005 and supported by measurements of limnological' parameters. Variations in water salinity appeared to be the key to all changes in water quality and phytoplankton biomass in Rosetta Estuary. Salinity ranged between 2.8 and 38.0 PSU. Water transparency showed a relatively low values with Secchi disc readings varying from 20 to $100 \mathrm{~cm}$. The $\mathrm{pH}$ values are ranging between 7.3 and 9.3. Dissolved oxygen levels indicated good aeration conditions $\left(4.0-13.2 \mathrm{mg} \mathrm{r}^{-1}\right)$. Nutrient salts varied widely, often occurring in high concentrations, with ranges of 0.2-19.9 $\mu \mathrm{g}$ at..$^{-1}$ for nitrate, $0.1-8.0 \mu \mathrm{g}$ at. $\mathrm{l}^{-}$ ${ }^{1}$ for nitrite, $0.0-4.9 \mu \mathrm{g}$ at. $1^{-1}$ for ammonia, 0.08-3.2 $\mu \mathrm{g}$ at. $\mathrm{l}^{-1}$ for phosphate and 1.2-46.0 $\mu \mathrm{g}$ at. $1^{-1}$ for silicate.

The phytoplankton community consisted of 152 species; Bacillariophyceae comprised the highest number of species (67) followed by Chlorophyceae (41), Cyanophyceae (18), Dinophyceae (16), Euglenophyceae (8), while Rhodophyceae and Dictyochophyceae were represented by only one species each. Chlorophyceae was the dominant group, forming $36.2 \%$ of the total phytoplankton biomass followed by Dinophyceae and Bacillariophyceae which ranked, respectively, 31.9\% and $20.8 \%$ of the total phytoplankton biomass. The phytoplankton biomass ranged between 0.05 and $5.73 \mathrm{mg} \mathrm{l}^{-1}$, with an annual average of $2.06 \mathrm{mg} \mathrm{1}^{-1}$. Highest biomasses were recorded in May and January due to the prevailing of freshwater species Scenedesmus quadricauda, Selenastrum gracile, Actinastrum hantzchii, Schroederia sp., Ankistrodesmus setigera and Pediastrum simplex. 
The statistical regression models performed showed that the most physico-chemical factors affecting the growth of phytoplankton biomass were water salinity and $\mathrm{pH}$ values.

\section{INTRODUCTION}

An estuary is a semi-enclosed coastal body of water with a free connection to the open sea and within which sea water is diluted by fresh water (Kimmeren, 2004). The continuous exchange between estuaries and the open sea allows rapid changes in salinity, temperature and nutrients. This variability has strong effects on both the composition and dynamics of the biota (Stacey, 2004).

Rosetta estuary lies at the lower reach of Rosetta Branch. It is partially isolated from the River Nile by the construction of a barrage. The Nile water in front of the barrage is maintained at a constant level, not exceeding $2.9 \mathrm{~m}$ above the mean sea level.

Rosetta estuary is $42 \mathrm{~km}$ long from the barrage to the outlet at the Mediterranean Sea. Its width varies between about 300 and $850 \mathrm{~m}$, with an average of $600 \mathrm{~m}$. The bottom topography of the estuary is irregular, presenting a succession of depressions, the middle one reaches $18 \mathrm{~m}$ in depth. The sill depth at the outlet rises to about $6 \mathrm{~m}$ from the surface.

Salinity is known to affect the structuring mechanism of the phytoplankton composition, since estuaries and coastal areas provide a transition zone between freshwater and marine species (Carstensen, 2004). However, there are large differences between ecosystems in the phytoplankton composition versus salinity. Although salinity can explain some of the changes in the phytoplankton community of estuaries, it can not account for all spatial variation (Muylaert et al. 2000).

Few investigations were carried out dealing with the distribution of phytoplankton in Rosetta estuary. Halim et al .(1976) and Zaghloul (1976) showed that phytoplankton in Rosetta Estuary was averaged 1:3 $\mathrm{x}$ $10^{6}$ units $1^{-1}$ during $1972-1973$, decreased to average $0.5 \times 10^{6}$ units $1^{-1}$ during 1986-1987 (Zaghloul, 1988), decreased to average $221 \times 10^{3}$ units $1^{-}$ 1 during 2004-2005 (Gharib, 2006).In the first two periods diatoms were more abundant followed by cyanophytes, while the last period was dominated by chlorophytes. The present study is the first to determine the quantitative composition of phytoplankton biomass is Rosetta Estuary, complemented by studying the effects of physico-chemical parameters on phytoplankton biomass. 


\section{MATERIALS AND METHODS}

Samples were collected at monthly intervals between February 2004 and January 2005 from seven fixed stations. The study included the end portion of Rosetta Branch at the connection with the Mediterranean Sea (Fig. 1).

Secchi disk of $25 \mathrm{~cm}$ diameter was used for measuring water transparency. Water temperature was measured with an ordinary thermometer graduated to $0.01^{\circ} \mathrm{C}$. The $\mathrm{pH}$ was measured in situ using portable glass electrode (Type: HANAA instrument). Dissolved oxygen was estimated by the modified Winkler method, nitrate, nitrite, ammonia, phosphate and silicate were determined spectrophotometrically (Strickland \& Parson, 1968).

Phytoplankton samples were immediately preserved in Lugol's iodine solution and were carried out using sedimentation technique as reported in the standard methods (A.P.H.A., 1985), and expressed in unit per liter. Phytoplankton biomass was calculated from recorded abundance and specific biovolume estimates, based on simple geometric solids (Rott, 1981) and assuming unit specific gravity. Grouping of phytoplankton species in terms of frequency coefficient was used following frequency groups to show the presence frequency of species in the community during the year. Frequency groups: $1-20 \%, 21-40 \%, 41-60 \%, 61-80 \%$ and $81-100 \%$ for rare, common, abundant, very abundant and continuous (existent throughout the year) species in the community, respectively. Frequency was calculated with the following equation: $f=\mathrm{Na}: \mathrm{N} n \times 100$ $\mathrm{Na}$ : presence number of species $\mathrm{A}$ in total sampling or individual number of A species; $\mathrm{N} n$ : total number of sampling or total individual number of whole species).

For phytoplankton identification, the following references were used: Heurck, 1986; Peragallo and Peragallo, 1897-1908; Hustedt, 1930; El-Nayal, 1935, 1936; Huber-Pestalozzi, 1938; Cupp, 1943; Khunnah, 1967.

Statistical analysis including correlation coefficient between phytoplankton biomass and physico-chemical parameters were calculated $(n=82)$.

Stepwise multiple regression at a confidence limit $95 \%(\mathrm{P}=0.05)$ were performed to establish multivariate regression equations between phytoplankton biomass and the physico-chemical parameters, using the statistical computer program Number Crunchier Statistical System 
(NCSS) by Hintze (1993). In this way it was possible to predict algae population dynamics.

\section{RESULTS}

\section{Physical and chemical features:}

\section{Temperature}

Water temperature in Rosetta Estuary showed limited regional variations and did not deviate from the normal seasonal fluctuations on the Egyptian coastal waters $\left(13-32^{\circ} \mathrm{C}\right)$. Figure (2) shows the trend of the values of surface temperature; the measures highlighted a sinusoidal temporal trend with the lowest values during winter $\left(13-19^{\circ} \mathrm{C}\right)$ and the highest in summer $\left(26-32^{\circ} \mathrm{C}\right)$, with an average amplitude of $17^{\circ} \mathrm{C}$.

A highly significant negative correlation $(r=-0.92, P<0.001)$ existed between temperature and dissolved oxygen. Other weak correlation $(r=-0.23, \mathrm{P} \leq 0.05)$ between temperature and phytoplankton biomass due to the effective other hydrological parameters on phytoplankton biomass rather than temperature. Correlations between temperature and other physical-chemical parameters were not significant except with reactive silicate $(r=-0.40, P<0.001)$.

\section{Salinity}

The variations in water salinity reflected the interaction between fresh Nile water and saline Mediterranean Sea. Stations 1, 2 and 3 which lying to the east, middle and west of the estuarine mouth had annual averages salinity 26.8, 23.5 and 33.0 PSU, respectively. While the inner stations 4, 5, 6 and 7 sustained lower averages; 16.3, 15.0, 15.4 and 13.1 PSU, respectively. The high salinity values recorded at station 3 , indicated that the flow of fresh Nile water usually takes the eastern direction. Highest salinity values were recorded in April and November (Fig. 2), while the lowest recorded in May and January reflected the effect of heavy fresh Nile water inflow.

Salinity values were negatively correlated with phytoplankton biomass $(r=-0.63, P<0.001)$ as well as all the nutrient salts, which mean that fresh Nile water rich in nutrient salts stimulate the growth of phytoplankton biomass. A highly significant positive correlations ( $r=$ $0.88, \mathrm{r}=0.65, \mathrm{r}=0.61, \mathrm{r}=0.58, \mathrm{r}=0.52$ ) were found between salinity and phytoplankton species like Protoperidinium conicum; Exuviaella compressa, Skeletonema costatum, Biddulphia smithü and Biddulphia alternans, respectively. 


\section{Water transparency:}

The fresh Nile water flow is the major cause of water turbidity in Rosetta Estuary, other factor of less importance is the intensive phytoplankton blooms which substantially reduced water transparency, the two variables - phytoplankton biomass and Secchi depth - showed an inverse relationship all the year round $(r=-0.52, P<0.001)$.

The annual cycle of water transparency showed a relatively low values for almost the whole year, with Secchi disc readings varying from 20 to $100 \mathrm{~cm}$ with an annual average of $42.6 \mathrm{~cm}$ (Fig. 3). The water in the inner stations was more turbid (Secchi depth $20-45 \mathrm{~cm}$ ) than in the outer stations due to the inflow of freshwater rich with silt and mud, this appear from the linear correlation between water salinity and Secchi disc readings $(\mathrm{r}=0.47, \mathrm{P}<0.001)$. In spite of the low Secchi disc reading, Rosetta Estuary did not detect any problem from phytoplankton blooms.

4. Hydrogen ion concentration:

The $\mathrm{pH}$ values were always above 7.0 , reaching $>9.0$ in May. Lower values were recoded in summer (July and August), where the values ranged between 7.3 and 8.0 (Fig. 4). The outer stations usually had lower $\mathrm{pH}$ values than the inner stations.

There were very important correlations between $\mathrm{pH}$ and nutrient salts ( $r=0.60$ for nitrate, $r=0.56$ for nitrite, $r=0.57$ for ammonia, $r=0.60$ for phosphate, $r=0.65$ for silicate). However, in terms of phytoplankton taxonomic groups, there was a strong significant correlations with green algae $(r=0.78, P<0.001)$, with diatoms $(r=0.62, P<0.001)$ and with blue green algae $(r=0.44, \mathrm{P}<0.001)$. On the other hand, dinoflagellates were not affected by $\mathrm{pH}$.

\section{Dissolved oxygen:}

Dissolved oxygen in Rosetta Estuary showed wide monthly variations due to the effect of temperature on oxygen solubility. This indicated from the strong negative correlation between dissolved oxygen and water temperature $(r=-0.92, \mathrm{P}<0.001)$. It varied between $4.0 \mathrm{mgO}_{2} \mathrm{l}^{-}$ ${ }^{1}$ (July) and $13.2 \mathrm{mgO}_{2} \mathrm{I}^{-1}$ (February) with an annual average of 7.62 $\mathrm{mgO}_{2} \mathrm{I}^{-1}$ (Fig. 4). Oxygen levels were generally above $4 \mathrm{mg} \mathrm{l^{-1 }}$, the threshold level of well oxygenation proposed by Huet (1973), often reaching values above $10 \mathrm{mg} \mathrm{l}^{-1}$. Lower values (less than $5 \mathrm{mg} \mathrm{1}^{-1}$ ) were recorded during summer (July-August) and higher values (>11 $\mathrm{mg} \mathrm{l}^{-1}$ ) occurred in winter (January-February). Due to their common dependence on photosynthetic processes, dissolved oxygen and $\mathrm{pH}$ showed a close 
linear correlation ( $=0.32, \mathrm{P} \leq 0.05$ ). Furthermore, oxygen exhibits a close correlation with green algae $(r=0.40, P<0.001)$ and no correlations were found with other phytoplankton taxonomic groups.

\section{Algal nutrientș:}

The continuous nutrient enrichment resulting from the discharged fresh 'Nile water, displayed different rangès of variation' for the different nutrient salts. The comparison between the physico-chemical parameters of the two periods 1986-1987 and 2004-2005 is summarized in Table (1). a- Nitrate:

The most important form of nitrogen is nitrate which formed $60.2 \%$ of the total inorganic nitrogen compounds. Nitrate concentrations ranged between 0.2 and $19.9 \mu \mathrm{g}$ at..$^{-1}$ with an annual average of $5.9 \mu \mathrm{g}$ at. $1^{-1}$. The principal feature is the high peak in May (Fig. 5) with an average of $14.5 \mu \mathrm{g}$ at..$^{-1}$, due to the remarkable inflow of fresh Nile water. A strong negative correlation between nitrate and both of salinity ( $r=$ $0.73, \mathrm{P}<0.001)$, and transparency $(\mathrm{r}=-0.42, \mathrm{P}<0.001)$. Lowest concentrations were observed in April (average $0.30 \mu \mathrm{g}$ at. $\mathrm{I}^{-1}$ ). Generally, nitrate concentrations in the outer stations were lower than that recorded at the inner stations (4-7), with averages of 3.35 and $7.72 \mu \mathrm{g}$ at. $\mathrm{l}^{-1}$, respectively.

\section{b- Nitrite}

As an intermediate between nitrate and ammonia, nitrite formed $21.4 \%$ of the total inorganic nitrogen compounds. Nitrite concentrations ranged between 0.1 and $8.0 \mu \mathrm{g}$ at. $\mathrm{l}^{-1}$ with an annual average of $2.1 \mu \mathrm{g}$ at. $1^{-1}$ (Fig. 5). The spatial pattern of nitrite appeared to be associated with the distribution of salinity $(r=-0.76, P<0.001)$. The average nitrite value in the inner stations appeared to be double than that recorded in the outer stations, amounted respectively, 2.88 and $1.23 \mu \mathrm{g}$ at. $\mathrm{l}^{-\mathrm{i}}$. Nitrite concentrations exhibited highest values in May (average $4.25 \mu \mathrm{g}$ at. $1^{-1}$ ) and lowest values in April (average $0.29 \mu \mathrm{g}$ at. $\mathrm{l}^{-1}$ ).

\section{c- Ammonia}

Ammonia was the lowest representative of dissolved inorganic nitrogen (18.4\%), displaying narrow range of variations in the outer stations (average $0.43-1.52 \mu \mathrm{g}$ at. $1^{-1}$ ) and the inner stations (average 2.17 $-2.84 \mu \mathrm{g}$ at. $\mathrm{I}^{-1}$ ) as compared to the other inorganic nitrogen compounds and with approximately similar monthly distribution. The concentration of ammonia ranged between complete depletion and $4.9 \mu \mathrm{g}$ at. $\mathrm{l}^{-1}$ with an annual average of $1.8 \mu \mathrm{g}$ at. $\mathrm{l}^{-1}$. 
d- Dissolved phosphate:

The concentration of dissolved phosphate in the investigated area fluctuated between 0.08 and $3.2 \mu \mathrm{g}$ at. $\mathrm{l}^{-1}$ with an annual average of 1.22 $\mu \mathrm{g}$ at. $\mathrm{l}^{-1}$ (Table 1). The concentrations of dissolved phosphate in the outer stations were generally lower than that recorded in the inner stations, amounted respectively, 0.75 and $1.57 \mu \mathrm{g}$ at. $1^{-1}$. Soluble reactive phosphorus concentrations remained above $0.7 \mu \mathrm{g}$ at..$^{-1}$, except in April and November (Fig. 6). The plot highlight a double winter peak, with values of $2.47 \mu \mathrm{g}$ at..$^{-1}$ in January and $1.64 \mu \mathrm{g}$ at..$^{-1}$ in February. Another high value was recorded in May (2.18 $\mu \mathrm{g}$ at. $\left.1^{-1}\right)$.

Generally, the estuary receives dissolved phosphate over the levels needed for the growth of phytoplankton. This appeared from the linear. correlation between dissolved phosphate and phytoplankton biomass ( $r=$ $0.57, \mathrm{P}<0.001$ ).

Nitrogen - phosphorus ratio:

In Rosetta Estuary, N/P ratio varies from one location to the other depending on the variability of water quality discharged into the estuary at the different times. However, the average ratio varied from 2:1 (April) and 10:1 (June) with an annual average of 8:1 for the study area. The theoretical assimilation ratio (16:1) was only observed in December.

e- Reactive silicate:

Generally, silicate is a good indicator of freshwater despersion and so, a strong negative correlation was found between silicate and salinity $(r=-0.78, P<0.001)$. Soluble reactive silicon concentrations were always above $2 \mu \mathrm{g}$ at. $1^{-1}$, but with wide oscillation during the year. A rapid decrease in silicate concentrations were obsersed in April (Fig. 6) having an average of $6.67 \mu \mathrm{g}$ at. $\mathrm{l}^{-1}$. Maximum silicate concentrations were observed in January with an average of $32.07 \mu \mathrm{Hg}$ at. $\mathrm{I}^{-1}$. The average silicate concentration in the outer stations (average $6.88 \mu \mathrm{g}$ at..$^{-1}$ ) was lower than the values in the inner stations (average $20.56 \mu \mathrm{g}$ at..$^{-1}$ ), with an annual average of $14.74 \mu \mathrm{g}$ at. $\mathrm{l}^{-1}$ for the study area.

Phytoplankton biomass and species composition:

A total of 152 species has been identified in Rosetta Estuary during the period from February 2004 to January 2005. The complete list is present in Table 2. The recorded species were some brackish, euryhaline, eurythermal and many of high salinity tolerante.

As it is usually found in estuarine region; Bacillariophyceae comprised the highest species number ( 31 genera, $67 \mathrm{spp}$ ) followed by the freshwater Chlorophyceae (41 species), Cyanophyceae (18 species) 
and Euglenophyceae (8 species), Dinophyceae showed remarkably low number (10 genera, 16 spp.). Rhodophyceae and Dictyochophyceae classes were represented by only one species each .

The temporal variation in the number of species is related to seasonal succession as well as to the growth pattern of different species in the community structure. Diatoms were more diversified in late spring (May) and autumn (November - December) than in other periods. However, chlorophytes were more diversified in May and January. Dinophyceae showed greatest numbers of species in June, while cyanophytes, in May and June. Maximum and minimum numbers of species were recorded in May (100 spp.) and March - April (56 spp.), respectively.

From the recorded species only 104 were measured and the others excluded because they were rare and with negligible volume. They were including 46 species of Bacillariophyceae, 28 of Chlorophyceae, 12 of Cyanophyceae, 13 of Dinophyceae and 5 of Euglenophyceae.

As it was represented numerically, Chlorophyceae was the dominant group, but it formed $36.2 \%$ of the total phytoplankton biomass (Table 3). Dinophyceae ranked the second group, constituted $31.9 \%$ of the total biomass, while it ranked numerically the third group formed only $3.4 \%$ of the total phytoplankton abundance. Cyanophyceae and Euglenophyceae formed respectively, 9.7 and $1.4 \%$ of the total phytoplankton biomass.

The outer stations $(1,2,3)$ had pronouncedly low average biomass, 1.16, 1.55 and $0.60 \mathrm{mg} \mathrm{l}^{-1}$, respectively, whereas the inner stations $(4,5,6,7)$ were more productive, with an average biomass fluctuating between $2.52 \mathrm{mg} \mathrm{l}^{-1}$ (station 7) and $2.89 \mathrm{mg} \mathrm{l}^{-1}$ (station 5).

At the outer stations (1-3); Dinophyceae was the dominant group formed $37 \%$ of the total phytoplankton biomass, of which Gymnodinium sp., Prorocentrum triestinum and Exuviaella compressa formed $82.5 \%$ of the total Dinophyceae.

Chlorophyceae took the second position, forming $30.4 \%$ of the total phytoplankton biomass, of which Scenedesmus quadricauda, Tetraedron minimum, Actinastrum hantzschü and Selenastrum gracile formed $67.1 \%$ of the total chlorophyte biomass.

Bacillariophyceae ranked the third group, whereas it formed $23 \%$ of the total phytoplankton biomass. Biddulphia alternans, $B$. rhombus, $B$. smithiu, Nitzschia palea, Cyclotella meneghiniana and Navicula gracilis constituted $93.6 \%$ of the total diatom biomass. 
At the inner stations (4-7), Chlorophyceae was the first group, it formed $42.9 \%$ of the total phytoplankton biomass, of which Scenedesmus quadricauda, Selenastrum gracile, Actinastrum hantzschü, Schrocieria sp., Ankistrodesmus setigera, Pediastrum simplex and Sphaerocysu, schroeteri formed more than $92 \%$ of the total green algae biomass. Dinophyceae ranked the second group $(30.7 \%$ of the total phytoplankton biomass), of which Gymnodinium sp., Exuviaella compressa and Oxytoxum sceptrum formed $89.4 \%$ of the total dinophyte biomass. Diatoms represented the third group (19.9\% of the total phytoplankton biomass) of which Cyclotella meneghiniana, Nitzschia palea, Skeletonema costatum, Synedra ulna and Cymbella lanceolata formed $72.6 \%$ of the total diatom biomass.

Cyanophyceae formed, respectively, 7.6 and $6.2 \%$ of the total phytoplankton biomass in the outer and inner stations. Dactylococcopsis acicularis, Oscillatoria irrigua and Oscillatoria limnerica were the dominant species.

Monthly fluctuations of the phytoplankton biomass:

The monthly variations of the total phytoplankton biomass together with the contribution by algal groups (Fig. 7) showed two biomass maxima; the first in May with prevailing fresh water at salinity less than $2.8 \mathrm{PSU}$, and amounted $2.2 \mathrm{mg} \mathrm{l}^{-1}$ in the outer stations and 4.54 $\mathrm{mg}^{-1}$ in the inner stations. The most important species were Actinastrum hantzschü, Scenedesmus quadricauda, Selenastrum gracile, Nitzschia palea, Ankistrodesmus setigera and Schroederia sp. The second peak in January amounted to $2.07 \mathrm{mg} \mathrm{I}^{-1}$ in the outer stations and $3.97 \mathrm{mg} \mathrm{l}^{-1}$ in the inner stations, resulting from the increased numbers of small coccoid green algae which constituted the main bulk of phytoplankton biomass as Tetraedron minimum, Scenedesmus quadricauda, Actinastrum hantzschu and the diatom Nitzschia patea.

Other increases were observed in February and March (St. 4) due to the absolute dominance of Skeletonema costatum, in June (Sts 5, 6) due to Prorocentrum triestinum, in November (Sts 4, 5) due to Exuviaella - compressa and, in December (Sts 4.5 ) due to Scenedesmus quadricaude and Exuviaella compressa (Table 4).

Statistical analysis

A series of simple statistical regression models were calculated according to Hintze (1993) describing the dependence of phytoplankton biomass on the measured physico-chemcial factors in Rosetta Estuary. 
Phytoplankton biomass $\left(\mathbf{m g} \mathrm{I}^{-1}\right)=-14.33+2.09 \mathrm{pH}-0.0276 \mathrm{~S} \%$

Dinoflagellate biomass $\left(\mathrm{mg} \mathrm{l}^{-1}\right)=-0.06183-0.269 \mathrm{NO}_{2}+0.049 \mathrm{R}=0.72$

0.025 temperature

$\left(\mathrm{R}^{2}=0.20\right)$

Chlorophyte biomass $\left(\mathrm{mg} \mathrm{I}^{-1}\right)=-8.136+1.12 \mathrm{pH}+0.135 \mathrm{NO}_{2}-0.0222$ temperature

$\left(\mathrm{R}^{2}=0.68\right)$

Bacillariophyte biomass $\left(\mathrm{mg} \mathrm{I}^{-\mathrm{i}}\right)=-2.333+0.394 \mathrm{pH}-0.0136 \mathrm{~S} \%$ $-0.0107 \mathrm{SiO}_{2}$

Cyanophyte biomass $=-1.40335+0.17 \mathrm{NH} 4-0.0203 \mathrm{SiO}^{2}+0.217 \mathrm{pH}-$ 0.0117 temperature

Water salinity and water temperature were the most effective environmental factors controlling phytoplankton biomass and their taxonomic groups. The $\mathrm{pH}$ value had a positive effect on total phytoplankton biomass and the major groups; Chlorophyceae and Bacillariophyceae, it was also had a positive effect on Cyanophyceae. The negative effect of dissolved silicate concentration was clearly appeared on the growth of diatoms and blue green algae.

The main manifestations of the phytoplankton biomass in Rosetta Estuary were the low phytoplankton biomass, the irregular water blooms and the influx of fresh Nile water was the main factor affecting the phytoplankton biomass.

\section{DISCUSSION}

The distribution of phytoplankton in estuaries and coastal waters is characterized by high spatial and temporal variability. The two major phytoplankton groups, Chlorophyta and Dinophyta, are strongly separated temporally by season, and spatially along the estuary according to flow and salinity. A weak correlation was found between temperature and phytoplankton biomass. Some phytoplankton taxa seem to be able to stand fairly wide temperature ranges. and maintain good growth rates, whereas other taxa seem to have small ranges of temperature tolerance (Hay et al., 1990). Chlorophyta, the dominant division especially at the inner stations, were be able to tolerate fluctuations in salinity, while Dinophyta, dominated by relatively few brackish water species, and occur at low discharges.

Secchi depth is one third of the euphotic zone (Goldman and Hom, 1994). In Rosetta Estuary, the fresh Nile water flow is the major cause of water turbidity. The annual average Secchi disc reading was $42.6 \mathrm{~cm}$, this value is noticeably lower than the previous recorded for that region 
(Zaghloul, 1976 \& 1988) and also than Damietta Branch (Abdel-Moati, 1981). Oxygen levels were generally above $4 \mathrm{mg} \mathrm{l}^{-1}$; the threshold level of well oxygenation proposed by Huet (1973), often reaching values above $10 \mathrm{mg} \mathrm{l}^{-1}$.

As in many other estuaries, nutrients appear to be less important than flow and salinity in regulating phytoplankton succession and biomass (Hamilton, 2001, Nikulina, 2003). The most important form of nitrogen is nitrate which formed $60.2 \%$ of the total inorganic nitrogen compounds. The element is considered as important source for phytoplankton growth (Parsons et al., 1990). Nitrate concentrations ranged between 0.2 and $19.9 \mu \mathrm{g}$ at..$^{-1}$ with an annual average of $5.9 \mu \mathrm{g}$ at. $l^{-1}$. The value was lower than the previous recorded by Samaan et al.(1996), who recorded the average nitrate concentration of $8.6 \mu \mathrm{g}$ at. ${ }^{-1}$ during 1986-1987. Generally, nitrate concentrations in the outer stations were lower than that recorded at the inner stations which means that the inflow of fresh Nile water is the main source of the nutrient salts in the estuary. Nitrite is the intermediate between nitrate and ammonia, formed $21.4 \%$ of the total inorganic nitrogen compounds, with an annual average of $2.1 \mu \mathrm{g}$ at. $1^{-1}$. This value appeared to be slightly higher than that recorded by Samaan et al. (1996). As stated by Parsons et al. (1990), like other inorganic major nutrient compounds, phosphorus is one of the most important inorganic nutrients used in growth of the phytoplankton, and its concentration should always be considered first in determining possible limitations in primary production. The average concentration of phosphate in the euphotic layers of productive temperate coastal waters is around $0.3 \mu \mathrm{g}$ at..$^{-1}$ (Abdella et al., 1995) and significantly lower after periods of phytoplankton blooms. In the Mediterranean Sea, values are extremly low, typically below $0.05 \mu \mathrm{g}$ at..$^{-1}$ in the euphotic zone (Stirn, 1988). The concentration of dissolved phosphate in Rosetta Estuary fluctuated between 0.08 and $3.2 \mu \mathrm{g}$ at..$^{-1}$ with an annual average value of $1.22 \mu \mathrm{g} \mathrm{at.} \mathrm{l}^{-1}$. The average value was lower than that recorded during 1986-1987 by Samaan et al. (1996). Generally, the estuary receives dissolved phosphate over the levels needed for the growth of phytoplankton. This appeared from the linear correlation between dissolved phosphate and phytoplankton biomass. However, neither nitrogen nor phosphorus may be actually limiting phytoplankton growth in Rosetta Estuary.

$\mathrm{N}$ : $\mathrm{P}$ ratios were usually below the theoretical assimilation ratio of 16:1 for the world's oceans. Mediterranean Sea in generally is classified 
as oligotrophic sea, its N/P ratio usually above 19:1 (Abdella et al., 1996). According to Chiaudani and Vighi (1978) marine algae are phosphorus limited when the N/P ratio is higher than 6 and nitrogen limited when tive ratio lower than 4.5 , while in the rang from 6 to 4.5 the two nutrients are near the optimal assimilative proportion. The average ratios of $\mathrm{N}: \mathrm{P}$ in Rosetta Estuary varied from 2:1 (April) and 10:1 (June) with an annual average of $8: 1$. The theoretical assimilation ratio (16:1) was only observed in December.

Soluble reactive silicon concentrations were always above $2 \mu \mathrm{g}$ at. $1^{-1}$, but with wide oscillation during the year and with an annual average of $14.74 \mu \mathrm{g}$ at. $\mathrm{l}^{-1}$ for the study area. The element is a good indicator of freshwater despersion and so a strong negative correlation was found between silicate and salinity .

The distribution of phytoplankton in estuaries and coastal waters is characterized by high spatial and temporal variability. Phytoplankton species of 7 classes were distinguished. The two major phytoplankton groups, Chlorophyta and Dinophyta, are strongly separated temporally by season, and spatially along the estuary according to flow and salinity. Chlorophyta exhibit the widest range of maximum potential growth rates and occur under a wide range of discharges, and were be able to tolerate fluctuations in salinity, while Dinophyta dominated by relatively few brackish water species, and occur at low discharges. As in many other estuaries, nutrients appear to be less important than flow and salinity in regulating phytoplankton succession and abundance (Hamilton,2001; Nikulina,2003). Due to the great salinity fluctuations in Rosetta estuary, the size spectra of phytoplankton species were larger than those in the River Nile or the Mediterranean Sea (Samaan et al. 1996; Zaghloul,1996; Zaghloul,1988). In the River Nile, the phytoplankton community comprised of 64 species, including 32 species of Chlorophyceae , 17 of Bacillariophyceae, 10 of Cyanophyceae, beside 4 species of Euglenophyceae and one of Dinophyceae . Melosira granulata var. angustissima , Cyclotella meneghiniana ,Pediastrum spp. , Scenedesmus spp, and Eudorina elegans formed the main bulk (Zaghloul,1988; Samaan et al., 1996). On the other hand; the algal community of the Western "arbour in. the Mediterranean Sea, represented by 72 species of which cyclotel! m meneghiniana, Nitzschia delicatissima, Prorocentrum cordatum and Euglena granulate were the dominant species (Zaghloul,1996). 
The number of species was also differed between the present study and previous works. Zaghloul (1988) recorded 57 species with maximum persistence to Melosira granulata, Pediastrum simplex and Microcystis aeruginosa. While Asterionella japonica and Thalassion:ema nitzschioides were dominant diatom species during 1972-1973 (Zaghloul,1976). These species were of minor constituents in the present study, in spite of sampling periods were similar and surface water temperature were almost identical to that of previous studies. Thus, the floral differences between the present results and previous studies suggest there is a large year-to-year, or even shorter variation in dominant species in Rosetta estuary, and the estuary is subject to huge inputs of terrigenous and anthropogenic nutrient from river discharge ,sewage and agricultural runoff, and the present study occupied the end portion of Rashid Branch strongly affected with saline Mediterranean water and both marine and freshwater phytoplankton are unable to grow quickly enough to build up a large population (Purdie,2002). The most dominant Dinophyte species was Prorocentrum triestinum which is estuarine species, best adapted for life in either fresh or salt water, and are marine in origin (Fox,2001), while Skeletonema costatum was the most diatom species especially in March occurred at salinity reached 17.8 PSU. The species is a neritic diatom with optimum salinity 19.5 PSU and declines as salinity deviates from this optimum (Cloern and Cheng,1981), and also is a euryhaline and eurythermal species which can grow quickly under eutrophic conditions ( Huang, et al, 2004 ). Salinity values were negatively correlated with phytoplankton biomass which means that fresh Nile water rich in nutrient salts stimulate the growth of phytoplankton biomass. A highly significant positive correlations were found between salinity and phytoplankton species like Protoperidinium conicum; Exuviaella compressa, Skeletonema costatum, Biddulphia smithü and Biddulphia alternans. .

Several of the dominant species, either marine or freshwater demonstrated different tolerance ranges to salinity variations. The freshwater chlorophytes, as well as the marine dinophytes, can withstand the widest salinity variations ( 2.8-39PSU). The freshwater chlorophytes Actinastrum hantzschii; Sphaerocystis schroeteri and Scenedesmus quadricauda extend their tolerance to 37 PSU. On the other hand, marine or brackish forms could not tolerate low salinity and were restricted to relatively high salinity (13-39 PSU) like Biddulphia alternans, Biddulphia smithii and Prorocentrum triestinum. Prorocentrum triestinum is an estuarine species, best adapted for life in either fresh or 
salt water and is marine in origin (Fox, 2001). Observation at seven station indicated that Rosetta Estuary sustained low to moderate phytoplankton biomass which was annually amounted $2.06 \mathrm{mg} \mathrm{I}^{-1}$ and is within the range considered as characteristic of meso-oligotrophic water (Vollenwider, 1968). This may be due to that, the present study occupied the end portion of Rosetta Branch, that strongly affected with saline Mediterranean water and both marine and freshwater phytoplankton are unable to grow quickly enough to build up a large population (Purdie, 2002).

The Rosetta plytoplank to biomass value $\left(2.06 \mathrm{mg} \mathrm{l}^{-1}\right)$ is lower than that recorded in Lake Burulls (north of the Nile Delta) which amounted $2.35 \mathrm{mg} \mathrm{l}^{-1}$ (El-Sherif, 1989). While in Lake Nasser, it amounted $22.91 \mathrm{mg} \mathrm{l}^{-1}$ (Zaghloul, 1985).

\section{REFERENCES}

Abdella, R.R.; Zaghloul, F.A. and Hussein, N.R. (1995). A statistical modelling of phytoplankton eutrophication in the Eastern Harbour, Alexandria, Egypt. Bull. Nat. Inst. of Oceanogr. \& Fish. A.R.E. $2 i(1)$ : $125-146$.

Abdel-Moati, A. (1981). Physico-chemical studies on Damietta branch of the Nile. M:Sc. Thesis, Alexandria University.

APHA, American Public Health Association (1985). Standard methods for examination of water and wastewater $16^{\text {th }} \mathrm{Ed}$. Washington DC. USA. $1268 \mathrm{pp}$.

Carstensen, J.; Conley, D.J. and Henriksen, P. (2004). Frequency, composition, and causes of summer phytoplankton blooms in a shallow coastal ecosystem, Kattegat. J. Limn. and Ocean., 49 : 190-201.

Chiaudani, G. and Vighi; M. ( 1978 ). Metodologia standard di saggio algare per lo studio della contaminazione della acque marine. Q:aadernidell' Instituto di Ricersa Sulle Acque, 39: 120. 
Cloren, J.E. and Cheng, R.T. ( 1981 ). Simulation Model of Skeletonema costatum Population Dynamics in Northern Sea Francisco Bay, California Estuarine. Costal and Shelf Science, 12: 83-100.

Cupp, E.E. ( 1943 ). Marine plankton diatoms of the west coast of North America. Bull. Scripps. Inst. Oceanog. 5: 238

El-Nayal, A.A. ( 1935 ). Egyptian Freshwater Algae. Bull. Fac. Sci. Cairo, 4: 106

El-Nayal, A.A. ( 1936 ). Contribution to our knowledge of the freshwater algae of Egypt. Bull. Fac. of Sci. Cairo, 1 (9): 1-31.

El-Sherif, Z.M. ( 1989 ). Biomass of the standing crop of phytoplankton in Lake Burollus (Egypt). Bull. Nat. Inst. Oceanogr. \& Fish ARE 15 (1): 179-189.

Fox, R. ( 2001 ). Limnology Lecture outlines, Environmental Science. Department of biology, Lander University, estuary.

Gharib, S.M. ( 2006 ). Effect of freshwater flow on the succession and abundance of phytoplankton in Rosetta Estuary, Egypt. Inter. J. of Oceans. \& Oceanography $I$ (2) in press.

Goldman, C.R. and Horn, A.J. 1994. Limnology Mc Graw-Hillo New York.

Halim, Y.; Samaan, A. and Zaghloul, F.A. ( 1976 ). Estuarine plankton of the Nile and the effect of freshwater. Phytoplankton. In "Fresh water on the sea" Ed., S. Skreslet, R., Leinebo, J.BL. Matthews and E. Sakshaug. The Association of Norwegian Oceanographers Oslo, pp153-164.

Hamilton, D.P. ( 2001 ). Effect of freshwater flow on the succession and biomass of phytoplankton in a seasonal estuary. Marine and Freshwater Research, 52 (6): 869-884.

Hay, B.J.; Honjo, S.; Kempe, S.; Ittekkot, V.A.; Degens, T.; Konuk, T. and Izdar, E. ( 1990 ). Interannual variability in particle flux in the south-western Black Sea. Deep-Sea Research. 37 (6): 911-928. 
Heurck, V.H. (1896): A treatise on the Diatomaceae. WilliamWestey and Son, 28, Essex, Strand, W.C. 559 pp.

Hintz, J.L. ( 1993 ). Number Cruncher Statistical System (NCSS) version 5.03.5/93.

Huang, L., Jian, W., Song, X., Huang, X., Liu, S., Qian, P. Yin, K. and Wu, M. ( 2004 ). Species diversity and distribution for phytoplankton of the Pearl River estuary during rainy and dry seasons. Marine Pollution Bull. 49: 30-39.

Huber-Pestalozz, G. ( 1938 ). Das phytoplankton des Suess Wassers. I, Teile, Die Binnengewasser. Stuttgart, 342 pp.

Huet, M. ( 1973 ). Text book of fish culture. Breeding and cultivation of fish. Fish. News Books Ltd, Survey, 436 pp.

Hustedt, F. ( 1930 ). Die Kieselalgen Deutschlands. Oesterreichs und der Schweiz. In Rabenhorst kryptogamen Glora; 920 pp, 542 Fig.

Khunnah, M.C. (1967). Chlorococcales, the Indian Council of Agricultural Research, New Delhi, Job Press Private Ltd: Kanpur, $363 \mathrm{pp}$.

Kimmeren, W.( 2004 ). Open water processes of the San Francisco Estuary. From Physical Forcing to Biological Responses, San Francisco Estuary and Watershed Science, 2 (1).

Muylaert, K., Sabbe, K: and Vyverman, W. (2000). Spatial and temporal dynamics of phytoplankton communities in freshwater tidal estuary (Schelde, Belgium). Estuarine, Coastal and Shelf Science 50: 673-687.

Nikulina, V.N.'(2003). Seasonal dynamics of phytoplankton in the inner Neva Estuary in the 1980s and 1990s. Oceanologia 45 (1): 25-39.

I ursons, T.R., Takahashi, M. and Hargrave, B. ( 1990 ). Biological Oceanographic Processes, Oxford: Pergamon Press. 
Peragallo, H. and Peragallo, M.( 1897-1908). Diatomees Marines de France et des Districts maritimes voisins. I-III (text and plates). Tempere Grez-surloing 1-491 pp.

Purdie, D. ( 2002 ). Plant production in Estuaries. Department of Oceanography. SOES 2009 Estuaries.

Rott, H.E. ( 1981 ). Some results from phytoplankton counting intercalibrations. Schweiz. Z. Hydrol. 43: 34-62.

Samaan, A.A.; Zaghloul, F.A. and Soliman, A.M. ( 1996 ). Phytoplankton diversity index in Rosetta Nile Branch, Egypt. Bull. Fac. Sci. Alex. Univ. 36 (1): 265-279.

Stacey, M. ( 2004 ). Monitoring the fluxes of salinity, pollution and phytoplankton into San Francisco Bay. Coastal Ocean. Research Uni. Of California, Berkeky R/CZ-170 (3,1): 2-29.

Stirn, J. ( 1988 ). Eutrophication in the Mediterranean Sea. Mediterranean Action Plan. Technical Reports Series. 21: 161-187.

Strickland, J.D.H. and Parsons, L.R. ( 1968 ). A practical handbook of sea water analysis. Fish. Res. Bd. Canada Bull. 311 pp.

Vollenweider, R.S. ( 1968 ). Scientific Fundamentals of the Eutrophication of Lakes and Flowing Waters, with Particular Reference to Nitrogen and phosphorus as factors of Eutrophication. Paris, Rep. Oceanization for Economic Cooperation and Development, DAS/CSI/68.27.pp 1-192.

Zaghloul, F.A. ( 1976 ). Plankton production and composition in the Nile waters between Edfina and Rashid in relation to environmental conditions M.Sc. Thesis, Faculty Science, Alex. Univ.

Zaghloul, F.A. ( 1985 ). Seasonal variations of plankton in Lake Nasser. Ph.D. Thesis, Suez Canal Univ., Fac. Sci., Zoology Dept.

Zaghloul, F.A. ( 1988 ). Phytoplankton production and composition in the Rosetta Estuary Bull. Inst. Oceangr. \& Fish. A.R.E.,14 (1): 243260.

Zaghloul, F.A.( 1996 ). Further studies on the assessment of eutrophication in Alexandria harbours, Egypt. Bull. Fac. Sci. Alex. Univ. 36 (1): 281-294. 
Table 1. Ranges and mean values of the phsico-chemical parameters during the periods 1986-1987 (after Samaan ef al., 1996) and 2004-2005 (present study) in Rosetta Estuary.

\begin{tabular}{|c|c|c|c|c|}
\hline \multirow[t]{2}{*}{$x^{2}$} & \multicolumn{2}{|c|}{ 1986-1987 } & \multicolumn{2}{|c|}{ 2004-2005 } \\
\hline & Range & Mean & Range & Mean \\
\hline Temperature ${ }^{\circ} \mathrm{C}$. & $15-34.5$ & 27.9 & $13-32$ & 25.2 \\
\hline Transparency $\mathrm{cm}$ & $20-220$ & 117.3 & $20-100$ & 42.6 \\
\hline $\mathrm{pH}$ & $7.5-9.2$ & & $7.3-9.1$ & B. 1 \\
\hline Salinity & $0.2-11.0$ & 4.06 & $2.8-36.3$ & 18.4 \\
\hline Dissolved oxygen $\mathrm{mg} \mathrm{r}^{-1}$ & $1.6-13.2$ & 4.7 & $4-13.2$ & 7.62 \\
\hline Nitrate $\mu g$ at. $\Gamma^{-1}$ & $0.52-65.41$ & 8.6 & $0.2-19.9$ & 5.9 \\
\hline Nitrite $\mu \mathrm{g}$ at. $\mathbf{I}^{-1}$ & $0.04-3.37$ & 1.37 & $0.1-8.0$ & 2.1 \\
\hline Ammonla ig a $\mathrm{r}^{-1}$ & & & $0.0-4.9$ & $\cdot 1.8$ \\
\hline Dissolved phosphate $\mu \mathrm{g}$ at. $\mathrm{r}^{-1}$ & $0.3-5.5$ & 2.52 & $0.2-3.1$ & 1.22 \\
\hline Reactive sillcate $\mu \mathrm{g}$ at. $r^{-1}$ & $4.4-138.3$ & 66.64 & $1.2-46.0$ & 14.74 \\
\hline Phytoplankton abundance $\times 10^{3}$ unit. $\left.\right|^{-9}$ & $8-3200$ & 500 & $1.64-3000$ & 221 \\
\hline Phytoplankton biomass mg. l $^{-1}$ & & & $0.05-5.73$ & 2.06 \\
\hline
\end{tabular}


Table 2. Species list and temporal variations of pluytoplaukton in Rosetta Estuary between February 2004 and January 2005 (1-20\%: rare, 21-40\%: common, 41-60\%: abundant, 61-80\%: very abundant, 81-100\%: continuous species, +: present, -: absent, q: quantitu(ively importunt).

\begin{tabular}{|c|c|c|c|c|c|c|c|c|c|c|c|c|c|}
\hline \multirow[t]{2}{*}{ Species } & \multicolumn{13}{|c|}{ Months } \\
\hline & $\mathbf{F}$ & $\mathbf{M}$ & $\mathbf{A}$ & $\mathbf{M}$ & $\mathbf{J}$ & $\mathbf{J}$ & $A$ & $\mathbf{S}$ & $\mathbf{0}$ & $\mathbf{N}$ & $\mathbf{D}$ & $\mathbf{J}$ & $\begin{array}{c}F \\
(\%)\end{array}$ \\
\hline Bacillariophycenc & & & & & & & & & & & & & \\
\hline Achuanhes brevipes $\mathrm{Ag}$ & - & + & + & + & - & - & - & + & + & + & + & + & 67 \\
\hline Achnanthes longipes Ag. & + & + & + & - & $t$ & + & + & + & + & + & + & $=$ & 83 \\
\hline Aclusanthes parvila kulz & - & $\therefore$ & - & - & - & + & $t$ & \pm & $t$ & \pm & \pm & $=$ & 50 \\
\hline Amphora ovalis kutz & - & - & - & + & + & - & 4 & - & + & - & + & + & 50 \\
\hline Anphiprora paluclosa Wm.Sn. & - & - & - & - & + & - & - & - & \pm & $\therefore$ & + & \pm & 25 \\
\hline Asterionella japonica Cleve \& O.F. Mulls. & 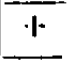 & + & $=$ & - & - & - & $=$ & $\therefore$ & - & + & - & - & 25 \\
\hline Asterolampra sp. & - & + & - & + & - & $=$ & - & - & - & $=$ & $\because$. & - & 17 \\
\hline Bacillariaporadoxa G.F.Gmel. & \pm & $=$ & - & + & + & + & - & $=$ & + & + & 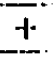 & + & $6 ?$ \\
\hline Baclericosirum hosalintum tauder & $=$ & $\therefore$ & - & - & - & - & - & $=$ & - & + & - & $\therefore$ & 8 \\
\hline Bicklulphia allernans (Bail), H.V.H. & + & + & + & + & - & - & + & + & - & + & - & - & 58 \\
\hline Bichlulphio lac vis Elir. & - & $\therefore$ & + & - & - & - & + & + & - & - & \pm & - & 33 \\
\hline Biddulphia mobiliensis Bail. Grun. & † & + & + & - & - & + & - & - & - & + & - & + & 50 \\
\hline Biddulphio rhombus (Elir), $\mathrm{Wm}$. & - & $\therefore$ & $t$ & $=$ & - & - & - & - & - & + & $=$ & - & 17 \\
\hline Bicddulphica smithu (Ralfs) H.V.H. & + & - & + & - & - & + & - & + & - & + & - & + & 50 \\
\hline Chaetoceros sp. & -1 & $\therefore$ & - & - & - & - & $=$ & - & \pm & \pm & - & - & 25 \\
\hline Cocconeis placenula Ehr. & + & \pm & + & + & - & - & - & - & + & - & + & + & 58 \\
\hline Coscinodiscus sp. & - & - & - & - & - & - & + & + & - & + & - & - & 25 \\
\hline Cyclotella comua (Ehr.), Kutz. & - & - & - & - & - & - & + & - & - & - & + & - & 17 \\
\hline Cyclocella meneghiniana kutz & + & + & + & + & + & + & + & + & + & \pm & + & + & 100 \\
\hline Cymbella lariceolata Ehr. & + & + & + & + & 4 & + & + & + & + & + & + & + & 100 \\
\hline Cymbella worgida Greg. & + & - & $=$ & + & + & + & + & + & + & + & + & - & 75 \\
\hline Epithemia zebra (Ehr.), Kutz & $=$ & 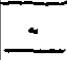 & - & $t$ & - & - & - & - & - & - & - & - & 8 \\
\hline Grammatophora angulosa Elır. & - & - & + & - & - & - & - & - & - & - & - & - & 8 \\
\hline Gomphonema olivaceum Lyngb. & - & 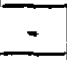 & - & + & \pm & + & + & + & + & + & + & - & 67 \\
\hline Hantzschia marina (Donkin) Grun. & + & $\therefore$ & - & - & - & 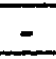 & - & - & - & + & - & - & 17 \\
\hline Hemiaulus haucku Grun. & - & + & + & - & - & - & - & - & + & - & - & $=$ & 25 \\
\hline Lauderia borealis Grun. & + & $\therefore$ & - & - & $=$ & - & - & $=$ & - & - & - & + & 17 \\
\hline Licmophora gracilis (Ehr.), Grun. & - & $t$ & $t$ & $t$ & + & + & $t$ & - & - & + & + & + & 75 \\
\hline Melosira cricipunctala Bachm. & $=$ & - & - & \pm & - & - & - & - & - & - & - & \pm & 17 \\
\hline Melosira granulàa (Ehr.), Ralfs & + & - & + & + & - & - & - & - & + & + & - & + & 50 \\
\hline Melosira jurgensu Ag. & - & $=$ & - & $=$ & - & $=$ & - & - & - & - & \pm & + & 17 \\
\hline Navicula borealis Ehr. & + & $\therefore$ & + & + & $t$ & + & - & + & + & + & + & + & 83 \\
\hline Navicula cryplocephala kutz. & + & + & + & + & + & + & + & $t$ & + & + & + & + & 100 \\
\hline Navicula didyma Ehr. & - & - & + & + & + & + & - & + & - & $t$ & + & - & 58 \\
\hline Navicula globiceps Greg. & - & $\therefore$ & - & - . & - & - & - & - & - & $t$ & - & - & 8 \\
\hline Navicula graciliș kutz. & + & + & + & + & + & + & + & + & + & $t$ & + & + & 100 \\
\hline Navicula gregaria Donk. & - & + & - & - & - & - & - & + & + & + & + & $t$ & 50 \\
\hline Novicula humerosa Breb. & - & - & - & $t$ & $t$ & \pm & - & - & - & - & - & - & 25 \\
\hline Navicula mutica kutz & + & + & + & + & + & - & + & + & + & \pm & + & + & 92 \\
\hline Navicula opima Grun. & - & + & - & - & + & + & - & + & + & + & + & - & 58 \\
\hline Navicula placentula Ehr. & - & + & + & \pm & $t$ & $t$ & $t$ & + & + & + & + & - & 83 \\
\hline Nizzschia acicularis Wm.Sm. & - & - & - & $t$ & $t$ & + & - & - & - & - & + & - & 33 \\
\hline
\end{tabular}




\begin{tabular}{|c|c|c|c|c|c|c|c|c|c|c|c|c|c|}
\hline \multirow{2}{*}{\multicolumn{14}{|c|}{ Table 2.(Continucd) }} \\
\hline & & & & & & & & & & & & & \\
\hline \multirow[t]{2}{*}{ Species } & \multicolumn{13}{|c|}{ Months } \\
\hline & $F$ & $\mathbf{M}$ & $\boldsymbol{A}$ & $\mathbf{M}$ & $J$ & $\boldsymbol{J}$ & $\mathbf{A}$ & $\mathbf{S}$ & 0 & $N$ & $\mathbf{D}$ & $\mathbf{J}$ & $\begin{array}{c}F \\
(\%)\end{array}$ \\
\hline Nitseftia apiculata(Greg.).Grun. & $t$ & - & $t$ & + & + & + & - & + & $\cdot$ & + & + & + & 75 \\
\hline Nitzschia closterium W.Sin. & - & + & - & + & + & + & + & + & + & $t$ & + & + & 83 \\
\hline Nizzschici frastullim (kutz), Grun. & + & + & + & + & + & + & - & + & + & + & + & + & 92 \\
\hline Nitzschia longissima (Breb.) Ralfs. & - & - & - & - & - & - & - & - & - & + & - & - & 8 \\
\hline Nitzsefhia microceplenta Gruns. & + & $f$ & $\overline{7}$ & + & + & + & + & + & + & + & + & + & 100 \\
\hline Nitzschici obinsa Win. Sm. & - & - & - & - & - & - & + & + & - & - & + & + & 33 \\
\hline Nitzschia paiea (Kutz) Wm. & $t$ & + & + & + & + & + & + & + & + & + & + & + & 100 \\
\hline Nifzschina pumclata (Wm.Sm.), Grun. & - & - & - & - & - & - & + & - & - & - & + & - & 17 \\
\hline Nizzschia sigma W'n.Sm. & + & + & + & $t$ & + & + & + & + & + & $t$ & + & + & 100 \\
\hline Nitzschia tryblionella Hantzsch. & + & - & - & + & - & $\overline{-}$ & -+ & + & - & - & - & - & 25 \\
\hline Plentrosigma elongatum W. Sunith & + & - & - & + & + & + & - & + & - & + & - & - & 50 \\
\hline Plearosigma mocram W/n. Sm. & - & - & - & $t$ & - & - & - & - & - & - & - & - & 8 \\
\hline Podosira stelliger (Baily) Mann. & - & - & - & + & - & - & - & - & + & + & r & + & 33 \\
\hline Rhizosolenia alata Bright & $\overline{-}$ & - & - & - & - & - & - & - & $t$ & $t$ & - & - & 17 \\
\hline Rhizosolenia seligera Brighit. & - & - & - & - & - & - & - & - & - & + & + & - & 17 \\
\hline Rhizosolenia stollerfodim H. Perag. & $\because$ & - & - & - & - & - & - & - & - & + & - & - & 8 \\
\hline Rhizosolenia styliformis Briglit. & - & - & $\because$ & - & - & - & - & - & - & + & - & - & 8 \\
\hline Skeletontma costasum (Grev.) Cl: $\mathrm{Q}$ & $t$ & + & + & - & - & + & - & - & + & + & + & - & 58 \\
\hline Symedro mirzschioides Grun. & - & + & + & + & + & + & - & + & \pm & + & + & + & 83 \\
\hline Synedia rampens kulz. & $\cdot$ & 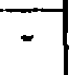 & 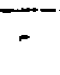 & 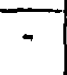 & - & - & - & - & - & $=$ & + & $=$ & 8 \\
\hline Symedra tabulata kutz & + & - & $\cdot$ & + & - & - & $\cdots$ & + & $=$ & + & - & - & 33 \\
\hline Synedra ulna (Nitzsch.), Elir. & + & + & + & + & - & - & - & $\because$ & + & 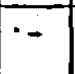 & + & + & 58 \\
\hline Thalassionema nitzschioides Hust. & - & - & - & + & - & + & - & - & - & + & - & - & .25 \\
\hline Thalassiosira decipiens (Grum). C. Jorg. & + & $\because$ & - & - & - & - & - & $\because$ & - & - & + & - & 17 \\
\hline Thalassiothrix franenfedu Grun. & - & - & $\therefore$ & - & - & - & - & $\because$ & - & + & - & - & 8 \\
\hline Chlorophyceac & & & & & & & & & & & & & \\
\hline Actinastrum hamtzschu Lagerh. & + & - & $=$ & + & - & - & - & - & $\therefore$ & + & + & $t$ & 42 \\
\hline Ankistrodesmis falcalus (Corda) Ralfs. & $t$ & + & + & + & + & $-\cdot$ & + & + & + & $\bar{t}$ & + & + & 92 \\
\hline Ankistrodesmmss fusiformis Corda & $t$ & - & - & + & - & - & - & - & - & - & $=$ & + & 25 \\
\hline Ankistroxlesinus spiralis (Turner) Lemm. & - & - & - & + & - & + & - & - & - & + & - & + & $\overline{33}$ \\
\hline Ankisirndesmuss setigerus (Schrod) G.S. west. & - & + & $t$ & + & + & + & - & + & + & + & + & + & 83 \\
\hline Carteria globasa korscl. & + & - & - & + & - & $t$ & + & + & - & - & + & + & 58 \\
\hline C'haracium actuminatum A. Bratun & + & + & + & + & - & + & - & + & + & + & + & + & 83 \\
\hline
\end{tabular}


Table 2. (Continued)

\begin{tabular}{|c|c|c|c|c|c|c|c|c|c|c|c|c|c|}
\hline \multirow[t]{2}{*}{ Species } & \multicolumn{13}{|c|}{ Months } \\
\hline & $F$ & $\mathbf{M}$ & A & $\mathbf{M}$ & $\mathbf{J}$ & $\mathbf{J}$ & $\mathbf{A}$ & $\mathbf{S}$ & $\mathbf{0}$ & $\mathbf{N}$ & D & $y$ & $\begin{array}{c} \\
(\%)\end{array}$ \\
\hline Chlamydomonas ovalis Pascl. & - & $=$ & - & $\therefore$ & - & $=$ & - & - & - & - & $t$ & 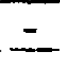 & 8 \\
\hline Chlorella vulgaris Bejer. & - & + & + & + & + & + & + & $t$ & + & - & + & $t$ & 83 \\
\hline Closterium actulum Breb. & - & + & + & + & + & $=$ & + & - & $=$ & - & - & + & 50 \\
\hline Coelasirum microporum Naeg. & - & - & - & + & - & - & - & - & - & - & - & + & 17 \\
\hline Cosmarim galeatum W. \& G.S. West. & $=$ & - & - & - & - & - & $=$ & - & + & $\because$ & - & - & 8 \\
\hline Crucigenia reciangularis (A.Braun) Gayq & + & + & - & + & + & - & + & + & + & + & + & + & 83 \\
\hline Crucigenia tetrapedia (Kirch)W.et west. & - & - & - & $t$ & + & - & - & + & + & + & + & + & 58 \\
\hline Crucigenia guadrala Morren. & + & $=$ & $=$ & + & - & - & + & + & + & - & + & + & 58 \\
\hline Glococystis gigas (kutz) Lag. & - & - & - & $t$ & - & - & - & - & $=$ & + & + & - & 25 \\
\hline Kirchneriolla contorta (Schm.) Bolı. & + & + & + & + & + & + & + & + & + & + & \pm & 4 & 100 \\
\hline Kirchneriella lumaris (kirch) Moeb. & + & $=$ & - & + & $t$ & - & - & + & + & + & + & + & 67 \\
\hline Micracinimm radianum (Chodat) ville. & + & - & - & + & - & - & 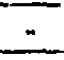 & $\therefore$ & 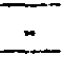 & - & $\because$ & - & 17 \\
\hline Micractinium pussillum Fresen. & - & - & - & + & - & - & - & - & - & - & - & + & 17 \\
\hline Oocystis borgei Snow. & - & - & - & + & - & - & - & - & - & - & - & $t$ & 17 \\
\hline Ooc)satis solitaria Wittr. & - & - & - & + & - & - & - & - & - & - & - & - & 8 \\
\hline Pediastrun clatiucatum (A. Braum) Lag. & - & - & + & \pm & - & $=$ & $=$ & - & \pm & $\div$ & - & - & 25 \\
\hline Pecliastrum duplex Meyen. & - & - & - & + & - & - & - & - & - & $=$ & - & + & 17 \\
\hline Pediasirnm simplex Meyen. & + & - & - & + & - & - & - & + & - & + & - & + & 42 \\
\hline Planklosphaeria gelatinosa G.M. Smith. & - & - & - & + & - & - & - & - & - & - & - & + & 17 \\
\hline Scenedesmus actuminatus (Lagerin)Chodat. & - & - & $=$ & + & - & $=$ & - & $=$ & - & - & - & + & 17 \\
\hline Sicenedesinus arcilatis (Lemm.) Leum. & - & + & - & 7 & - & - & - & - & - & $\overline{-}$ & $\overline{-}$ & + & 25 \\
\hline Scenedesimus bijigatus (Turp.) Kutz. & + & - & $=$ & + & $T$ & - & - & + & $t$ & - & - & + & 50 \\
\hline Scenedesmus dimorphus Turp. & - & + & - & + & \pm & - & - & - & - & - & $\cdot$ & $t$ & 33 \\
\hline Scenedesmus obliguus (Turp.) kutz. & - & - & - & $t$ & + & - & $=$ & - & - & + & + & + & 12 \\
\hline Scenedesmus quadricanda (Turp.) Breb.q. & + & + & + & + & + & - & + & + & + & + & + & + & 92 \\
\hline Schroederia sp. & + & + & + & + & + & + & + & + & + & $\therefore$ & $\therefore$ & - & 75 \\
\hline Selenastrum gracile Reinsch. & + & - & - & + & + & + & + & + & + & + & + & + & 83 \\
\hline Sphaerocyst is schroeteri Chodat. & - & + & $=$ & $t$ & - & $=$ & + & - & - & - & - & + & 33 \\
\hline Staurasirume terracertim Ralf. & - & - & $=$ & $t$ & - & - & - & - & - & - & - & + & 17 \\
\hline Tetrachlorella alternans Beijer. & - & - & - & $t$ & - & $\therefore$ & - & - & - & - & - & - & 8 \\
\hline Tetraedron caudalum (Corda) Hansg. & - & - & $=$ & + & + & $\therefore$ & - & - & - & $=$ & - & + & 25 \\
\hline Tetraedron minimum (A. Braun) Hansg. & - & + & - & + & + & + & - & + & - & - & + & + & 58 \\
\hline Tetraedron muticum A. Braun. & \pm & - & - & + & $=$ & + & + & + & - & - & + & + & 58 \\
\hline Tetraedion protejforme (Turn) Braulh. & - & - & $=$ & + & \pm & - & - & $=$ & - & $=$ & $=$ & $=$ & 17 \\
\hline Cyanophyceae & & & & & & & & & & & & & \\
\hline Anabaena circinalis Rabh. & - & - & $\therefore$ & $=$ & + & - & - & - & - & - & + & $\because$ & 17 \\
\hline $\begin{array}{l}\text { Anabaenopsis circularis (G.S. West) Wol. \& } \\
\text { Mill. }\end{array}$ & - & - & $=$ & - & - & - & - & - & + & - & - & - & 8 \\
\hline Anabaenopsis flos-aquae (Lyngb.) Breb. & + & - & - & $=$ & - & - & $=$ & - & $=$ & - & - & - & 8 \\
\hline Aphanocapsa delicalissima W. et G.S. West. & - & - & 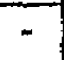 & + & - & - & $=$ & + & - & - & - & 7 & 25 \\
\hline Chroococcus dispersus (Kelssl.) Lemm. & - & + & - & + & $\overline{-}$ & 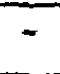 & - & - & + & - & + & + & 72 \\
\hline
\end{tabular}




\begin{tabular}{|c|c|c|c|c|c|c|c|c|c|c|c|c|c|}
\hline Chroococcus minutus $(\mathrm{Kg}$. Naeg. & + & - & - & $t$ & + & - & + & + & - & - & - & + & 50 \\
\hline Dactylococcopsis acicularis Lemm. & + & + & + & $t$ & + & + & + & + & $t$ & - & + & + & 92 \\
\hline Dactylococcopsis irregularis G.M. Smith. & + & $\mp$ & + & + & - & + & $\because$ & $t$ & - & $\overline{-}$ & $\mp$ & + & 67 \\
\hline Lyngbya limnetica Lemm. & + & - & - & + & + & $t$ & - & $t$ & + & $t_{i}$ & $\therefore$ & - & 58 \\
\hline Oscillaroria brevis (Kg.) Goin. & $\overline{-}$ & - & + & + & + & $\bar{t}$ & $t$ & - & + & - & + & - & 58 \\
\hline Oscillatoria irrigua $\mathrm{Kg}$ & - & \pm & + & + & + & + & + & $t$ & - & \pm & - & + & 75 \\
\hline Oscillatoria limnefica Lemm. & - & + & - & + & + & + & + & $f$ & + & + & + & + & 83 \\
\hline Oscillaroria tenius Agardh. & + & + & $t$ & + & + & + & + & $t$ & + & - & + & - & 83 \\
\hline Oscillaloria princeps Vauch. & \pm & $=$ & $t$ & - & - & - & + & - & - & + & + & $\therefore$ & $\overrightarrow{42}$ \\
\hline Merismopedia punctata Lemm. & $\overrightarrow{-}$ & - & + & + & + & - & - & - & + & - & - & - & 33 \\
\hline Mficrocysfis aeruginosa $\mathrm{K}_{\mathrm{g}}$ & - & $=$ & - & \pm & + & - & - & + & - & - & - & \pm & 33 \\
\hline Spirulina laxissima G.S. West. & - & $=$ & - & - & \pm & + & - & - & - & - & - & - & 17 \\
\hline Spirulina platensis (Nordst) Gei. & - & $=$ & - & + & $=$ & - & - & $=$ & - & - & 7 & - & 8 \\
\hline \multicolumn{14}{|l|}{ Dinophyceae } \\
\hline Ceratium furca (Elır.) Clap. \& Lach. & - & - & - & + & 4 & + & - & + & - & - & $=$ & - & 42 \\
\hline Ceratium fustus (Ehr.) Dujar & - & - & - & $=$ & - & - & - & + & - & - & $=$ & - & 8 \\
\hline Dinophysis canckara Saville-Kent. & - & + & + & $\because$ & + & $\therefore$ & - & - & $\because$ & 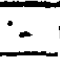 & - & - & 25 \\
\hline Exicvidlla.compressa Ostenfeld & \pm & \pm & + & \pm & \pm & $t$ & \pm & + & + & + & + & - & 92 \\
\hline Oxploxum sceptrmm (Slein) Sch. & + & + & + & - & + & - & - & - & - & + & + & - & 50 \\
\hline Gontanlax conjumcraWood. & - & $\therefore$ & - & - & + & - & - & - & - & - & - & - & 8 \\
\hline Gonyaulex polygramma Stein. & + & + & - & - & - & + & + & + & - & - & - & - & 42 \\
\hline Gymuodinium sp. & + & $=$ & + & + & + & + & + & + & - & + & + & - & 75 \\
\hline Gyrodinimm falcatum Kofoid \& Sivezy. & - & - & - & - & + & - & - & + & - & - & $=$ & - & 17 \\
\hline Prorocentrim micans Elurenb. & + & \pm & + & + & + & + & + & + & + & + & + & + & 100 \\
\hline Prorocenirnmi iriestimm Schiller. & - & $=$ & + & + & + & + & + & - & - & - & - & $\sim$ & 42 \\
\hline Protopcitidinium copricum Gran. & + & + & \pm & + & + & - & + & + & + & \pm & \pm & - & 83 \\
\hline Protoperidinizm cercosus (Paulsen) Balech. & - & + & - & $=$ & + & - & - & - & + & - & - & - & 25 \\
\hline Proloperidinium conicoides (Paulsen) Baled. & + & + & + & + & + & + & + & - & - & + & - & - & 67 \\
\hline Proloperidinium deprossum (Bailey) Balech. & - & \pm & + & - & + & - & + & - & - & - & - & - & 33 \\
\hline Protoperidinium trochoideum (Stein) Lemm. & + & - & - & + & + & + & + & + & - & + & - & - & $\overline{58}$ \\
\hline \multicolumn{14}{|l|}{ Euglenophycene } \\
\hline Eugiena acus Elır. & + & + & $t$ & + & + & + & + & - & - & + & + & - & 75 \\
\hline Eaglena caudata Hubner. & + & - & $t$ & - & + & + & + & - & - & - & - & $\cdot$ & $\overline{42}$ \\
\hline Euglena ehrenber'gii Klebs. & - & + & - & - & $=$ & - & $t$ & - & - & + & - & - & 25 \\
\hline Euglena granulata (Klebs.) Lemm. & $t$ & - & - & - & + & + & - & - & + & + & + & - & 50 \\
\hline Euglena klebsus Delf. & $\therefore$ & - & - & - & $\because$ & - & $=$ & - & - & + & - & - & 8 \\
\hline Euglena spirogyra Elır. & + & + & + & + & 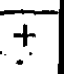 & - & $=$ & - & $t$ & - & - & - & 50 \\
\hline Phacus pyrum (Ehr.) Stein. & - & - & $=$ & + & - & $\because$ & + & $\therefore$ & - & $=$ & - & - & 17 \\
\hline Pheicus irigueter (Ehr, ) Duj. & - & - & $=$ & + & - & - & - & - & - & $=$ & - & - & 8 \\
\hline \multicolumn{14}{|l|}{ Rhodopliycere } \\
\hline Compsopogon caeruleus Mont. & - & - & - & $\overline{-}$ & - & + & + & - & - & - & - & - & 17 \\
\hline \multicolumn{14}{|l|}{ Dictyochopliycenc. } \\
\hline Dictyocha fibula Ehr. & - & - & - & $\therefore$ & + & + & + & + & \pm & + & - & - & 50 \\
\hline
\end{tabular}




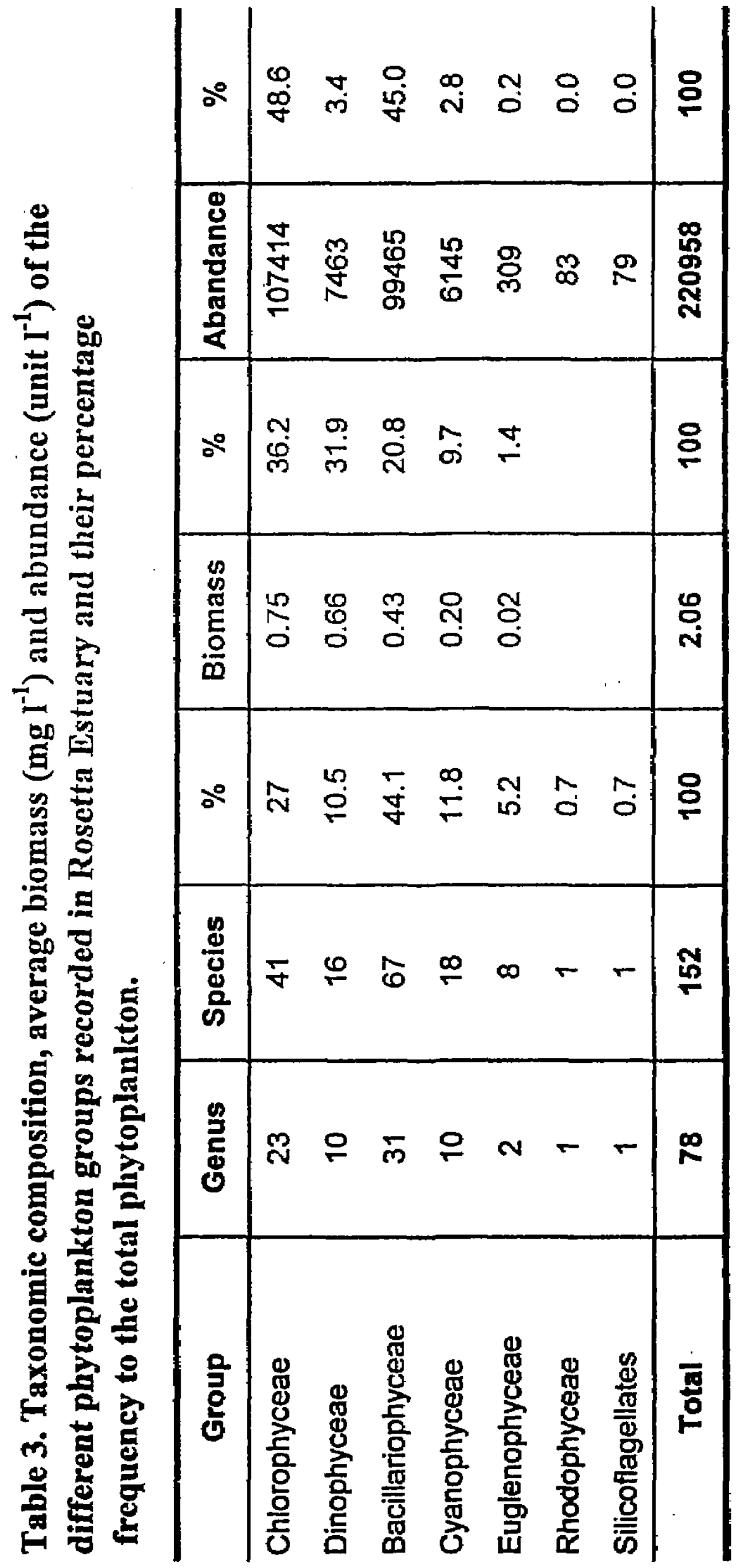


Table 4 . Summary of the monthly dominant species and the frequent associated in Rosetta Estuary.

\begin{tabular}{|c|c|c|}
\hline Month & Dominant species & Associated species \\
\hline $\begin{array}{l}\text { February } \\
2004\end{array}$ & $\begin{array}{l}\text { Ankistrodesmus fusiformis } \\
\text { Cyclotella meneghiniana }\end{array}$ & $\begin{array}{l}\text { Dactylococcopsis } \\
\text { acicularis Skeletonema } \\
\text { costatum }\end{array}$ \\
\hline March & Skeletonema costatum & $\begin{array}{l}\text { Protoperidinium conicum } \\
\text { Oxytoxum sceptrum }\end{array}$ \\
\hline April & Ankistrodesmus setigerus & Schroederia sp. \\
\hline May & $\begin{array}{l}\text { Actinastrum hantzschu } \\
\text { Scenedesmus quadricauda }\end{array}$ & $\begin{array}{l}\text { Selenastrum gracile } \\
\text { Nitzschia palea. }\end{array}$ \\
\hline June & $\begin{array}{l}\text { Prorocentrum triestinum } \\
\text { Gymnodinium sp. }\end{array}$ & $\begin{array}{l}\text { Selenastrum gracile } \\
\text { Schroederia sp. }\end{array}$ \\
\hline July & Cymbella lanceolata & Navicula placentula \\
\hline August & $\begin{array}{l}\text { Gymnodinium sp. } \\
\text { Gomphonema olivaceum }\end{array}$ & Cyclotella comita \\
\hline Sep. & Cyclotella meneghiniana & $\begin{array}{l}\text { Gymmodinium sp. } \\
\text { Cymbella lanceolata }\end{array}$ \\
\hline Oct. & Nitzschia palea. & Navicula borealis \\
\hline Nov. & Exuviella compressa & Navicula gracilis \\
\hline Dec. & $\begin{array}{l}\text { Exuviella compressa } \\
\text { Scenedesmus quadricauda }\end{array}$ & Nitzschia palea. \\
\hline $\begin{array}{c}\text { January } \\
2005 \\
.\end{array}$ & $\begin{array}{l}\text { Pediastrum simplex } \\
\text { Tetraedron minimum } \\
\text { Scenedesmus quadricauda }\end{array}$ & $\begin{array}{l}\text { Actinastrum hantzschu! } \\
\text { Selenastrum gracile }\end{array}$ \\
\hline
\end{tabular}




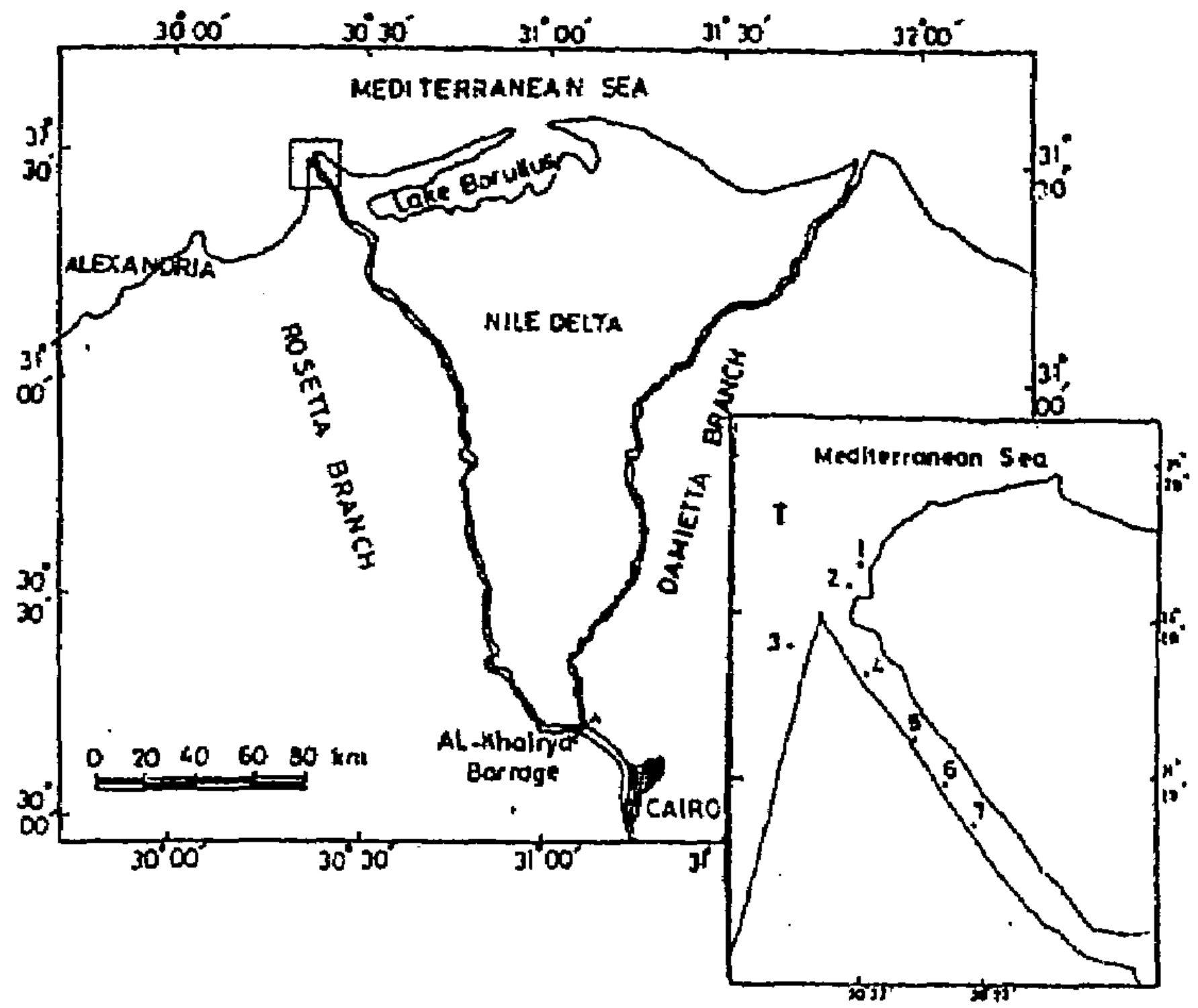

Fig. 1. Study area and sampling stations. 


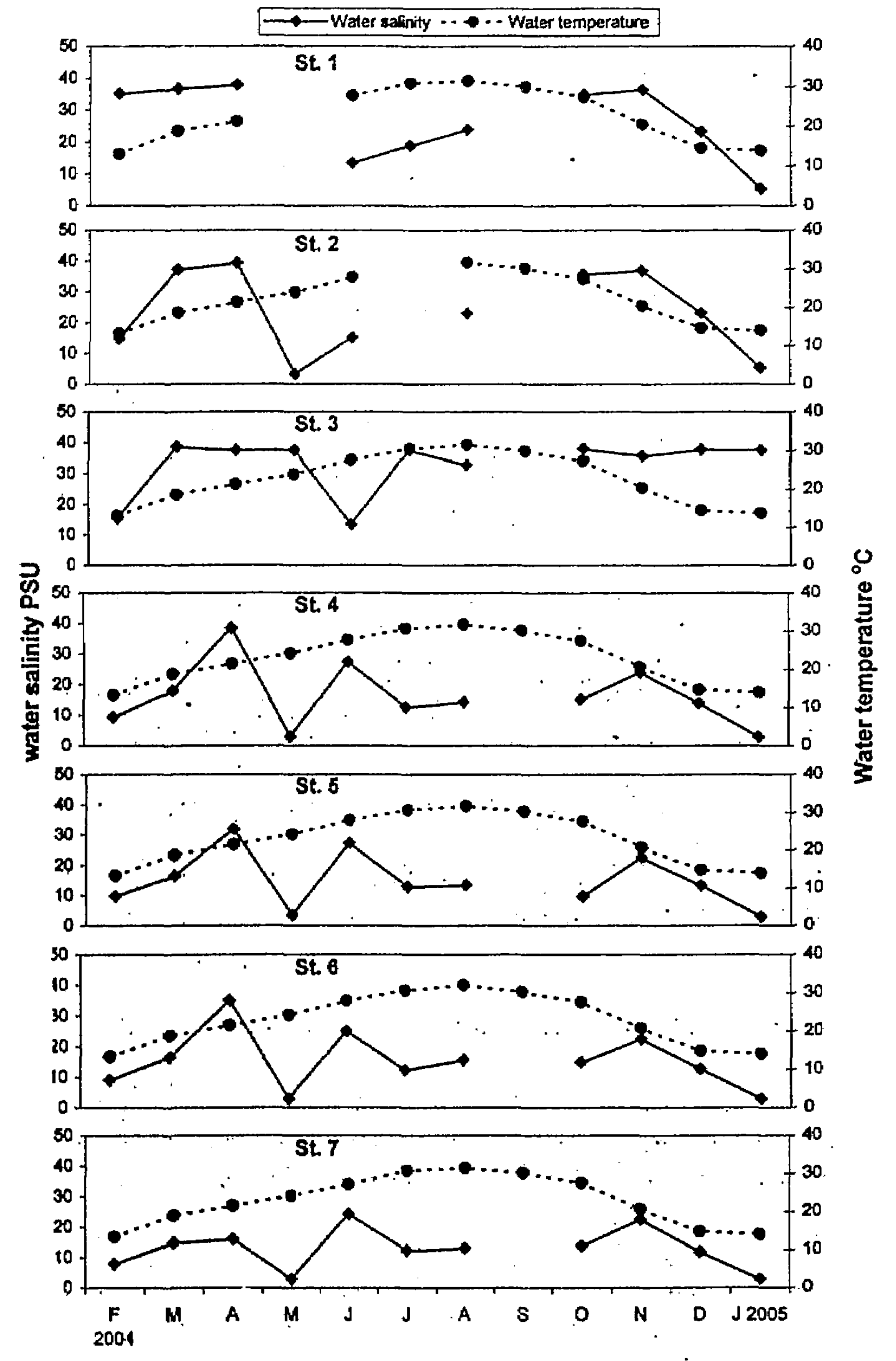

Fig. 2. Monthly variation of water sallnity and water temperature at the different stations in Rosetta Esuary. 


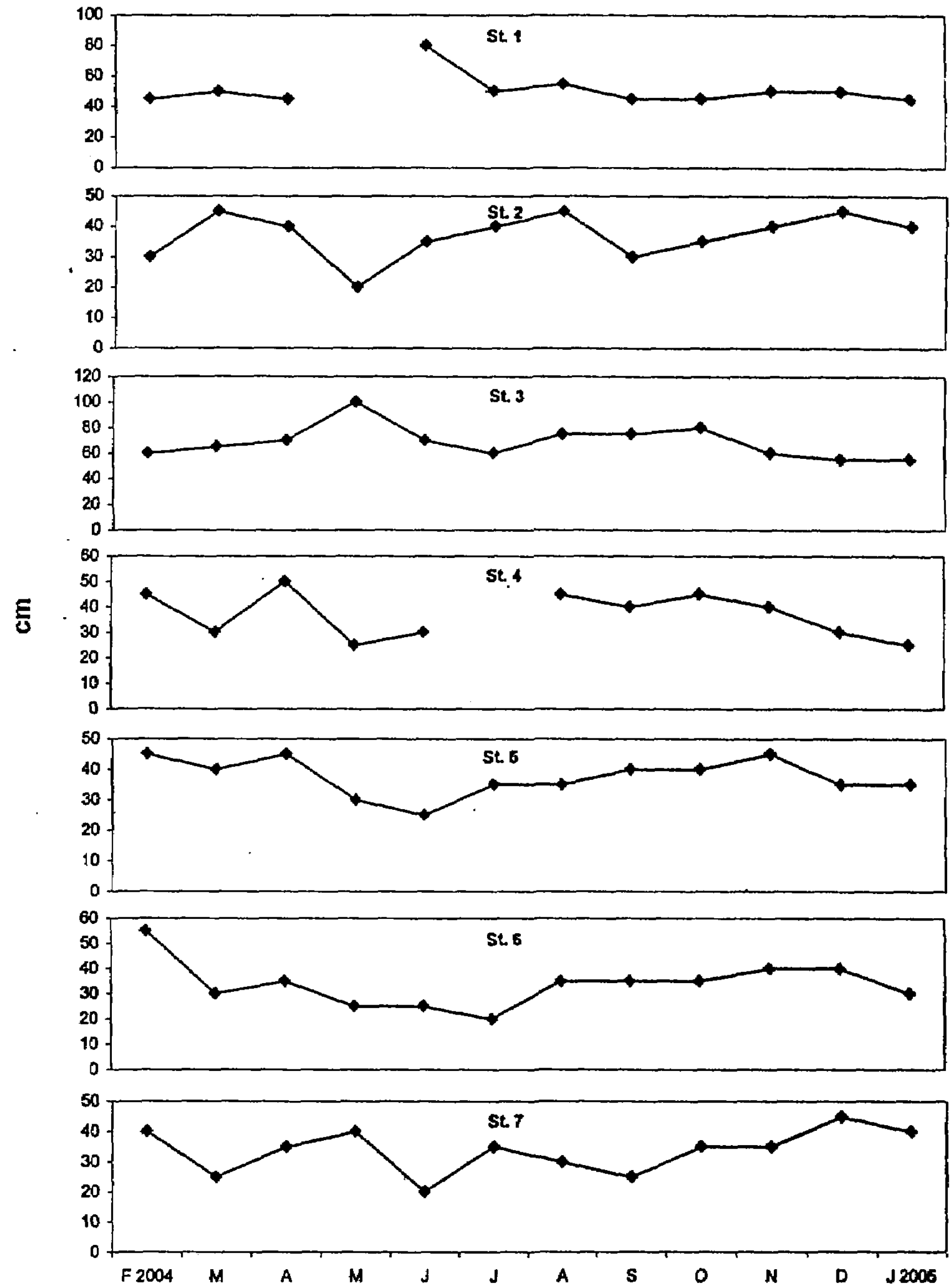

Fig.3. Monthly variation of water transparency at the different stations in Rosetta Estuary. 


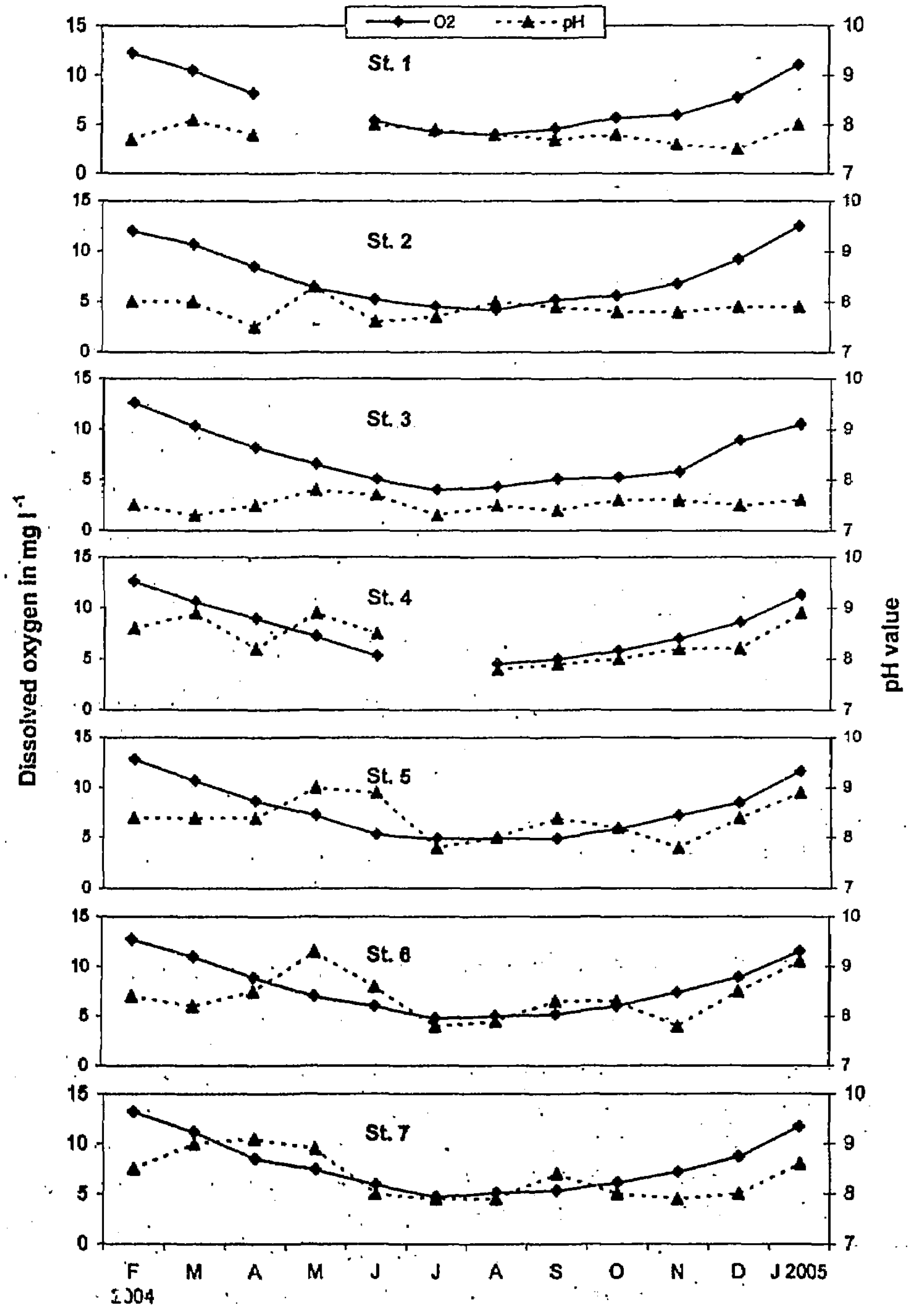

Fig.4. Monthly changes in dissolved oxygen and $\mathrm{pH}$ values at the sampling stations. 

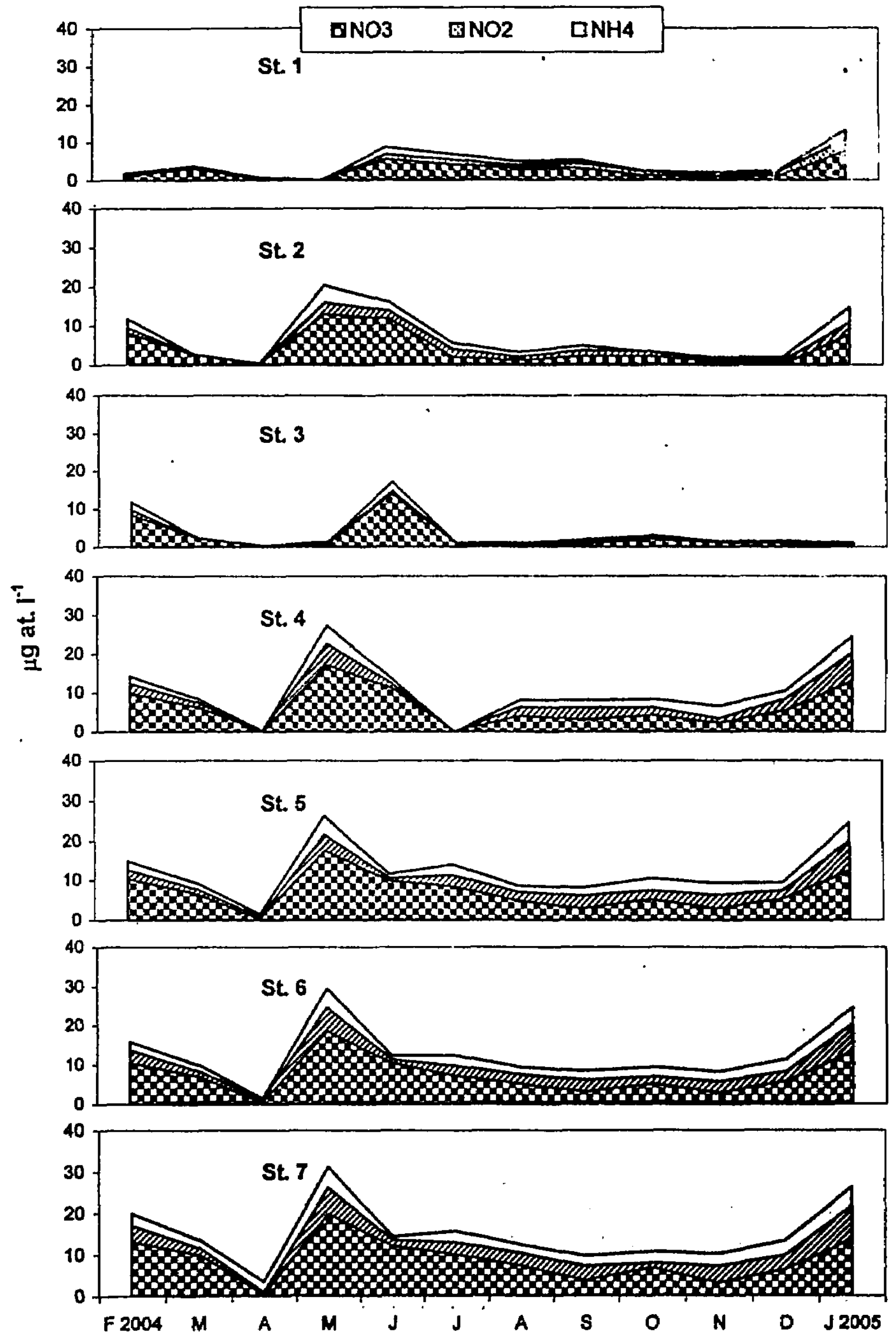

Fig. 5. Monthly change in inorganic nitrogen compounds at the sampling stations. 

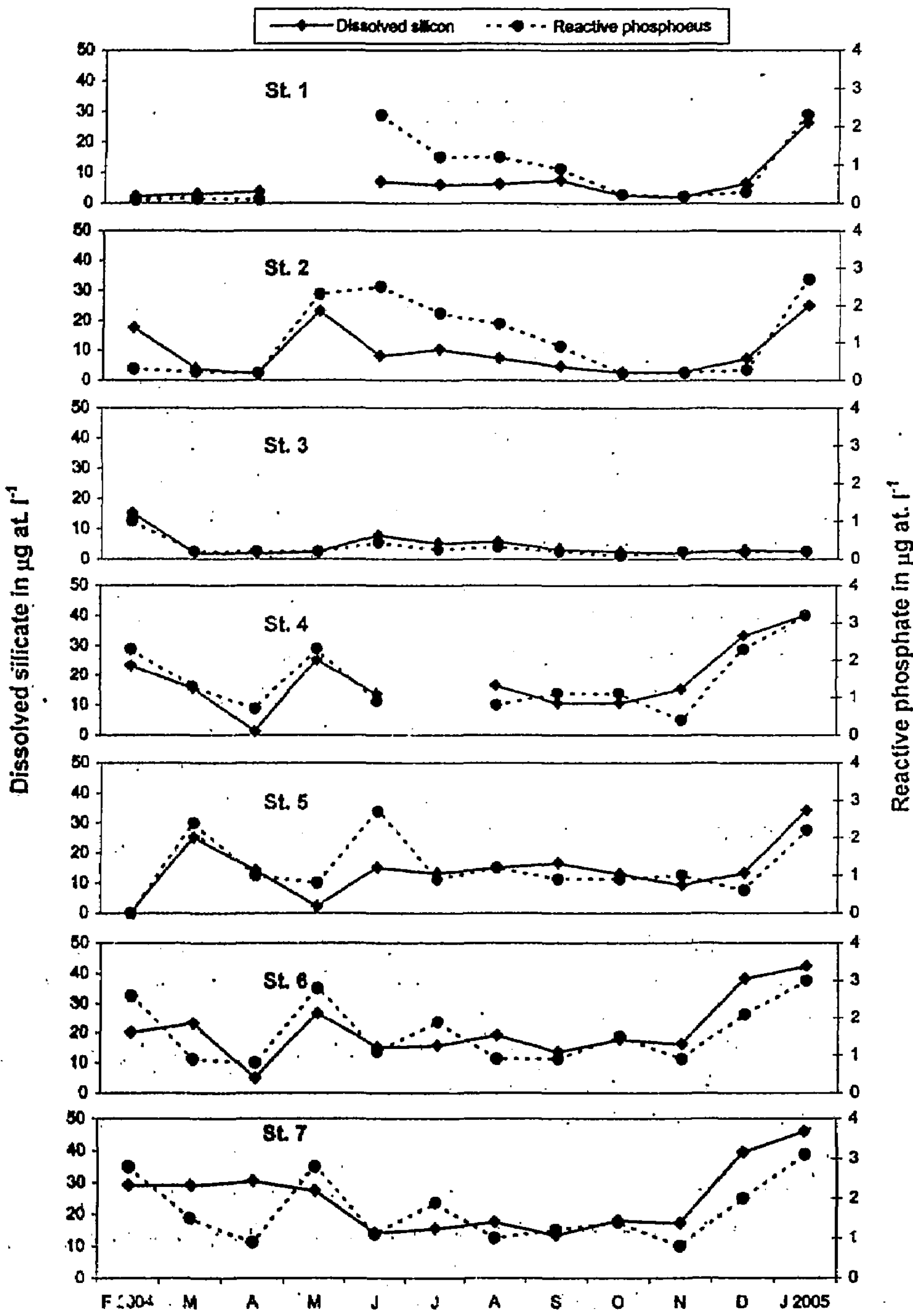

Fig. 6. Monthiy change In dissolved silicate and reactive phosphate at the sampling stations. 
OChlorophyceae DDinophyceae DBacillariophyceas DOther groups
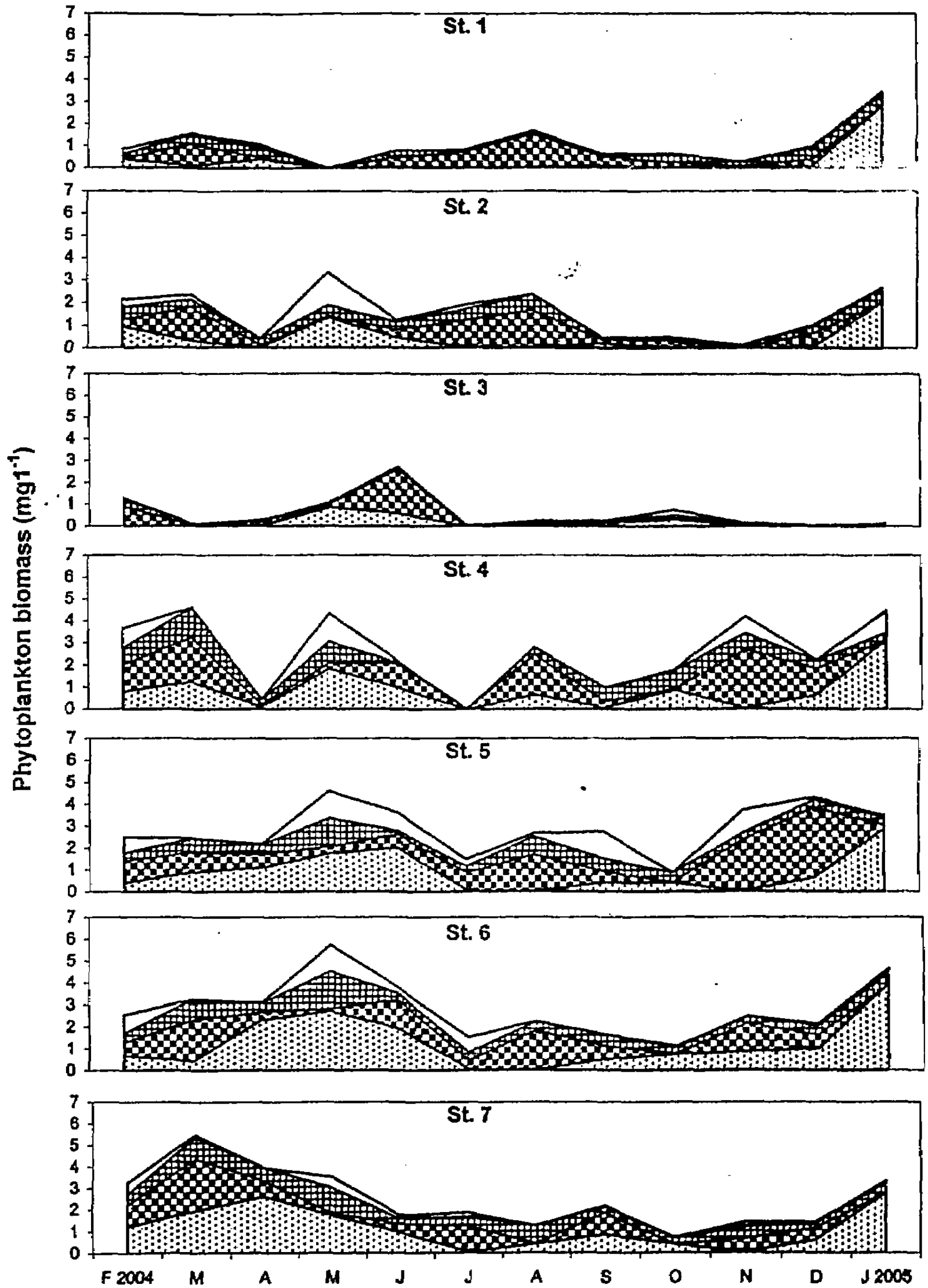

Fig. 7. Monthly variation of phytoplankton biomass together with the contribution by the main algal groups at the different stations in Rosetta Estuary. 